\title{
Jewish Identity, Values, and Religion in a Globalized World: A Study of Late Adolescents
}

\author{
Vassilis Saroglou and Benoît Hanique \\ Université catholique de Louvain
}

\begin{abstract}
Multiple identities are becoming an increasingly important issue in a globalized world. This study examines the interference of Jewish identity with other collective identities, national and transnational, as well as the influence of religion and values on Jewish and other collective identities in Jewish late adolescents in Belgium. We compared data with those of a previous study on native Belgians and Muslim immigrants (Saroglou \& Galand, 2004) and found similarities between Jews and the other two groups in the hierarchies of collective identities and values; however, Jews differed in their weak European identity and the considerable importance to them of autonomy and self-enhancement values (power and achievement). Jewish cultural identity was unrelated to other collective identities, but a shift from a Jewish identity to a new, Belgian identity or to a broad, transnational identity (or both) was occasionally related to low levels of attachment to religion, tradition, power, security, and hedonism and to high levels of universalism, autonomy, and conformity.
\end{abstract}

Jewish identity is a complex reality that may face important challenges in an age of globalization, when "there is little to distinguish one group from another" (Dashefsky, Lazerwitz, \& Tabory, 2003, p. 260). This may be particularly true for younger Jews living in the United States or in European countries where they constitute a minority within a large multiethnic society or within European "national" countries with increasing multiculturalism. For instance, research in the United States by Cohen and Eisen (2000) and Fishman (2004) on, respectively, moderately religious Jews and mixed marriages of Jews with non-Jews deals with the question of whether integration into a postmodern, open-minded plural-

Correspondence should be addressed to Vassilis Saroglou, Université catholique de Louvain, Dept. of Psychology, Centre for Psychology of Religion, Place du Cardinal Mercier 10 B-1348, Louvainla-Neuve, Belgium. E-mail: Vassilis.Saroglou@psp.ucl.ac.be 
ist society threatens the maintenance of Jewish identity. Many questions relative to the issue of multiple identities may arise that are of some importance both for researchers and for political decision makers. Is Jewish identity still a distinct reality? Is there a distinction between the religious and the nonreligious components of Jewish identity? How does Jewish identity, or how do Jewish identities, interfere with other collective identities, especially national and transnational ones? What is the role of religion? What are the values that underpin a strong Jewish identity or openness to a globalized world? Finally, how similar or different are Jews in comparison with "natives" or cultural minority groups such as Muslim immigrants in terms of ethnic identity, religion, national and transnational identities, value importance and hierarchy, and the way that these realities are interrelated?

This study investigates these questions in the context of a specific European country, Belgium, which presents the following characteristics. Belgium is historically a Catholic-predominant country, although today it is one of the most secularized countries in Europe (Halman, 2001), and a sizable proportion of the population defines itself as being atheistic or "freethinking," and many social structures reflect this (Voyé \& Dobbelaere, 2001). Jews constitute a considerable minority that can be characterized as being rather discrete and progressive as well as being well integrated both economically and socially into Belgian society (Schreiber, 2002). As a community, Jews have been in Belgium for centuries, with different immigration periods from the Middle Ages to the 20th century (Schreiber, 1996); thus, they are not perceived as "immigrants." With the exception of several sad cases, Belgian Jews were not persecuted by local authorities during the Second World War, at least not at a level similar to other European countries; in many cases, they were saved by elements within Belgian society (e.g., Brachfeld, 2001; Steinberg, 1998). Finally, Muslim immigrants, mostly from Mediterranean countries, constitute a much more important minority, numerically speaking, and are seen by native Belgians as a rather homogeneous out-group; they have arrived as immigrants, on average, more recently than Jews, and their socioeconomic integration into Belgian society is considered to be problematic and still in progress (e.g., Khader \& Roosens, 2004).

\section{JEWISH IDENTITY AND MULTIPLE COLLECTIVE IDENTITIES}

A series of questions relative to Jewish identity and its interference with multiple collective identities was investigated among late adolescents from Jewish families in Belgium. These questions included, first, the intensity of Jewish identity and its comparison with the strengths of national (Belgian) and transnational identitiesthat is, identification as a citizen of the world and as European (Belgium has been 
one of the leading countries in the construction of the European Union and its consolidation process). Second, with regard to both ethnic and other national and transnational collective identities, Jews were compared with native Belgians and Muslims born of immigrants from Mediterranean countries (data from Saroglou \& Galand, 2004). Third, intercorrelations between Jewish identity and the other collective identities were investigated.

High levels of discrepancy between a strong origin identity and a weak adopted-country identity, as well as a negative correlation between these two identities, can be considered as indicating a low degree of integration into the adopted country and a high level of self-perceived distinctiveness on the part of Jews. Given the long history of the Jewish community within Belgian society, we expected the opposite. We also expected Jews to have a stronger sense of Belgian identity than that of their Muslim immigrant peers from Mediterranean countries. Similarly, high levels of discrepancy between Jewish identity and transnational identities, as well as a negative correlation between them, could be seen as suggesting a difficulty in the construction of multiple identities within a globalized world.

\section{VALUES AND COLLECTIVE IDENTITIES}

Another set of questions concerned values and their relation to collective identities. First, using the Schwartz model of values (1992), we investigated the hierarchy of values in Jewish late adolescents, and we compared their value hierarchy and importance with those of native Belgian and Muslim immigrant late adolescents (data from Saroglou \& Galand, 2004). Second, we studied the impact of values on in-group-focused identity (Jewish) and openness toward other groups, as measured by Belgian identity, transnational identities, and low out-group aversion.

With regard to the first question, there is strong evidence of a double reality. On the one hand, many studies using the Schwartz model (1992) suggest a pancultural consensus on the hierarchy of importance of the 10 major values (Schwartz \& Bardi, 2001). We found, in line with this evidence, a strong similarity of value hierarchy among late adolescents in Belgium-specifically, that among those who were native, Muslim immigrant, and non-Muslim immigrant (Saroglou \& Galand, 2004). On the other hand, there is evidence that differences in the importance of particular values can be observed as a function of various psychological and social realities, such as personality traits (Roccas, Sagiv, Schwartz, \& Knafo, 2002), religiousness (Saroglou, Delpierre, \& Dernelle, 2004), age, cultural group, and country (Schwartz \& Bardi, 2001; Schwartz \& Sagiv, 1995). We thus expected a similarity between Jews and native Belgians or Muslim immigrants on value hierarchy and some differences on the mean importance attributed to some values. For instance, native Belgians, when compared to Muslim immigrants, tended to find tra- 
dition less important and stimulation more important; they were also less religious and valued spirituality less (Saroglou \& Galand, 2004).

With regard to the second question, there is some evidence that conservation values (tradition, conformity, and security), universalism, and autonomy may be relevant for out-group-related attitudes, whereas the role of hedonistic values is unclear. For instance, Israeli Jews who disliked conservation values and valued universalism and self-direction were found to be more inclined toward contact with an out-group (Israeli Muslims; Sagiv \& Schwartz, 1995). Low importance that was attributed to conservation values and high importance that was attributed to universalism and self-direction predicted strong transnational identities among late adolescents in Belgium, where, in addition, hedonistic values were also positive predictors of these identities among immigrants (Saroglou \& Galand, 2004). In contrast, high importance that was attributed to conservation values, stimulation, and achievement predicted strong Flemish nationalism among Dutchspeaking Belgians (Duriez, Luyten, Snauwaert, \& Hutsebaut, 2002). We thus expected these values to play a role in Jewish versus other national or transnational identities and out-group-related attitudes.

\section{RELIGION AND COLLECTIVE IDENTITIES}

Religion, both in terms of religious institutions and personal religiousness, may play an important role in the preservation of ethnic identity among immigrants (Ebaugh, 2003). There is considerable evidence that religiousness is positively related to a strong national identity in European countries (Bréchon, 2003; Campiche, 1997) and the United States (e.g., Burris, Branscombe, \& Jackson, 2000) and to attachment to the country of origin among immigrants (Ebaugh, 2003; Saroglou \& Galand, 2004). It is, however, less clear whether the role of religion in consolidating ethnic origin identities extends to being an obstacle to the creation of new identities, especially broader, multiple, and transnational ones. For instance, in Mediterranean, usually monoreligious, countries-but not in Western European ones-religious young people tend not to attribute great importance to universalism (Saroglou et al., 2004). However, in some cases, religion may have a positive role in openness to multiculturalism (Burris et al., 2000; Canada), strong identification as a citizen of the world (Saroglou \& Galand, 2004; Belgium), and resistance to xenophobia among young (18- to 29-year-old) but not older Europeans (Bréchon, 2003). Integrating sets of results of this kind, Saroglou and Galand (2004) suggested that, although religion may be primarily conceived as contributing to traditional ethnic identities, some aspects of religion, at least in some socioeconomic contexts, may also contribute to widening collective identities, not necessarily in terms of real universalism, but at least of extended transnational in-groups (for instance, the Umma or the Church). 
Accordingly, we investigated whether religiousness in Jewish late adolescents might imply strong Jewish identity and whether religiousness and Jewish religious identity might imply national (Belgian) and transnational identities and openness to out-groups. The question is particularly important as far as "Jewishness" and "Judaism" are concerned. First, there is evidence that an important overlap exists between religious and nonreligious aspects of Jewish identity (Dashefsky et al., 2003). Second, there is a widespread idea that, in comparison with other monotheistic traditions, Judaism is less universalist and more in-group focused. For instance, as we are reminded by Cohen and Eisen (2000) and Fishman (2004), American Jews have been perceived for a long time by other Americans as being uneasy with the idea of mixed marriage and as being characterized by a historical "tribalism." Third, whereas in the United States the religious dimension in Jewish identity seems to be increasing or is in the process of being transformed to the detriment of its ethnic character, in other countries, Jewish identity is and functions more as an ethnic identity (Cohen \& Eisen, 2000; Elazar, 1999; Liebman, 2001).

\section{METHOD}

\section{Participants}

We contacted the directors of the two Jewish secondary schools located in Brussels. After we explained the aims of the research to them, they agreed to have their 5th- and 6th-year students take part in the study (the 6th year is the last year for the students; we selected these ages so that we could have data comparable with the data in Saroglou \& Galand, 2004). Forms were distributed in class, and participants were asked to fill them in individually during class. The participants were explicitly informed that it was their right not to take part in the study, if they did not wish to. Seventy-one forms were collected. With the exception of one student, all students present on the days of data collection took part in the study. Of those taking part, $60 \%$ were boys and $40 \%$ were girls. The answers to our sociodemographic questions showed that 63 of the 71 participants were born in Belgium (56 in Brussels), 2 in Paris, 2 in the former Soviet Union, and 4 in Israel. The mean age was $16.86(S D=0.83)$; ages varied from 16 to 19 . The study was carried out in January 2004.

\section{Measures}

Collective identities. Four questions, involving a 7-point Likert format from 1 (not at all) to 7 (absolutely), were used to assess the following collective identities: "How much do you define yourself in terms of identity as ... 1. Citizen of the world; 2. European; 3. Belgian; and 4. Jewish?" A previous study (Saroglou \& 
Galand, 2004) asked the first three questions and a similar fourth one ("other, please specify"; immigrants reported identification with their countries of origin), and it provided interesting and meaningful hierarchies of these identities; mean differences between native Belgians, Muslim, and other immigrants; and associations with external constructs (values, religiousness, and identity status).

Values. The Schwartz Value Survey (1992) includes 56 single-value items representing groups of 10 types of values: tradition, conformity, security, power, achievement, self-direction, hedonism, stimulation, universalism, and benevolence. Respondents rate the importance of each value item ("a guiding principle in my life") on a 9-point scale ranging from 7 (of supreme importance) to -1 (opposed to my values). The structure of the 10 values has shown cross-cultural stability across dozens of countries and has been found to relate meaningfully to real behaviors, such as prosocial, antisocial, environmental, political, consumer, and intellectual behaviors. Definitions of the values and corresponding single-value items, as well as the way that structural relations between the 10 values may be spatially represented, can be found in many published papers (e.g., Schwartz, 1992; Schwartz \& Bardi, 2001).

Religion. We administered eight items (using a 7-point Likert scale) that usually reflect two religious dimensions-classic religiousness (three items) and emotional religion (four items) — and a one-item spirituality index (e.g., Saroglou \& Galand, 2004). In the present data, a principal component analysis followed by varimax rotation replicated a two-factor structure where, as expected, importance of God, importance of religion in life, and frequency of prayer formed a Classic Religiousness factor (loadings, .90 to .70) and where importance of emotional experience, community aspect, meaning and values, and personal experience in religion formed an Emotional Religion factor (loadings, .77 to .54). However, importance of spirituality in life had almost equivalent loadings with each factor. Given that the addition of this latter item to the first factor did not increase reliability $(\alpha=$ .84 ) whereas its addition to the second one did increase reliability (from .59 to .68), we included it in this latter factor, labeled thereafter as the Emotional Religion-Spirituality factor (see also, Saroglou, 2002).

Jewish identity. Participants were asked to report in a 7-point Likert-format scale from 1 (not important) to 7 (very important) their opinion on eight items:

In Judaism, this is important for me: (a) the study of texts, the Talmud, and the Torah; (b) the memory and history of the Jewish people; (c) learning Hebrew; (d) feeling close to the State of Israel; (e) feasts and religious ceremonies; (f) synagogue attendance; (g) prayer; and (h) maintaining my Jewish name. 
TABLE 1

Factor Analysis of Items Measuring Jewish Identity

\begin{tabular}{lll}
\hline Jewish identity & $I$ & $I I$ \\
\hline Religious & & \\
$\quad$ Prayer & .93 & \\
Synagogue attendance & .85 & \\
Religious ceremonies & .72 & .87 \\
Study of texts (Torah, Talmud) & .66 & .67 \\
Cultural & & .62 \\
Close to the State of Israel & & .55 \\
Memory, history of Jewish people & .35 & \\
Learning Hebrew & & \\
Maintaining a Jewish name & & \\
\hline
\end{tabular}

Note. Only loadings higher than .30 are mentioned.

A principal component analysis of the eight Jewish identity items followed by a varimax rotation indicated a clear two-factor structure (see Table 1) distinguishing between a Religious Identity factor and a Cultural Identity factor and explaining $60.65 \%$ of the total variance. Reliabilities of the factors were satisfactory (.84 and .68 ), and the two factors were only moderately intercorrelated, $r=.40$.

Out-group aversion. Four questions were introduced asking for opinions reflecting closed-versus-open attitudes towards out-groups, as manifested in concrete examples:

Mixed marriage: "A friend of yours announces to you that $\mathrm{s} / \mathrm{he}$ is getting married to a non-Belgian"; 7-point scale from 1 (I disapprove) to 7 (I approve).

Insecurity as a function of immigration (in Belgium, one associates this question immediately with Muslims): "There is no relationship between insecurity and immigration" (reverse); similar to the above 7-point scale.

Muslims as being unintegrated: "What did you think of the Marseillaise being whistled at in the Stade de France?" (event that happened in 2001 when young French people of Arab descent booed the French national anthem during a football game between France and Algeria). Participants were asked to make one choice from three possible answers: "Obvious proof of the failure of integration policies. These people do not belong in France" (3). "It's unfortunate, but we shouldn't blow things out of proportion" (2). "We should all be listening to these people, for we are all responsible for the climate of hate that we maintain through our hidden racism" (1). 
The Islamic veil: "What do you think of the wearing of the Islamic veil in schools?" Participants could make one choice between three possible answers: "It should be allowed in the name of the individual and religious freedom that is a constitutive part of our democracy" (1). "Very worrisome. A step away from obligatory prayer and holy pilgrimage to Mecca" (3). "It's unfortunate, but we shouldn't blow things out of proportion" (2).

The items were not selected because Muslims should a priori be considered the out-group for Jews. The first reason was that Belgium is not a country with the large ethnic variety that one can find, for instance, in the United States, where many other groups constitute out-groups with regard to one's own. Muslims of immigrant origin, mostly with their roots in Morocco and Turkey, constitute the main minority (and visible) group. In addition, given that our hypothesis was that young Jews would identify themselves also as Belgians, we did not include items on native Belgians as a possible out-group for Jews. Finally, and possibly because of the international political situation, the media and the press have heightened perception of the Israeli-Palestinian conflict as a religious conflict, and several anti-Semitic acts have taken place in recent years in Belgium in which Jews were the victims of aggression by young Arabs/Muslims.

A global score of out-group aversion was computed by considering the answers as scores on a 3-point ordinal scale (the first two questions were trichotomized). Reliability was low, $\alpha=.51$ but still not unimportant given the variety of questions and formats of answers. We thus included this variable in our analyses, and, as detailed here, it was predictive of interesting associations.

Comparative data. To compare the Jewish late adolescents of our study with their native Belgian peers $(n=81)$ and Muslim immigrant peers $(n=72)$, we used data from a previous study (Saroglou \& Galand, 2004). In that study, participants of the same age $(M=17.8, S D=1.3)$ and educational level (secondary school students) and from urban areas in Belgium, including Brussels, were administered (among other measures) the Schwartz Value Survey, the collective-identities questions, and the religiousness measure. However, those data differed from the present ones in two respects. First, data from Saroglou and Galand (2004) were collected in January and February 2002, only 4-5 months after the September 11 attacks, whereas the present data were collected 2 years later. Second, native Belgians and Muslim immigrants (and children of immigrants) studied together at the same public schools (which were, moreover, Catholic run), whereas the Jewish participants in this study came from Jewish schools whose students come exclusively from Jewish families. Nevertheless, selecting our Jewish participants as we did seemed a good compromise: $\mathrm{Nu}$ merically, it would be next to impossible to otherwise find and constitute a meaningful sample of young Jews, even if we contacted dozens of public schools in Brussels and even without taking into account uncertainty regarding whether these partici- 
pants would easily provide self-identification as Jews. In addition, the two schools to which we had access are not seen as being essentially religious or Orthodox, unlike other schools in other Belgian cities (e.g., Antwerp).

\section{RESULTS}

\section{Hierarchy and Mean Importance of Collective Identities and Values}

For Jewish participants, means and standard deviations are presented in Table 2. For comparison purposes, means of collective identities and values for Jews, Muslims, and native Belgians are presented in Figures 1 and 2, respectively. Among Jews, Jewish identity was highly valued in comparison with other identities - that is, Belgian, $F(1,70)=145.82$; European, $F(1,70)=112.25$; and cosmopolitan, $F(1,70)=104.70$; for all $F \mathrm{~s}, p<.001$. The latter three identities did not differ significantly from each other. Comparisons of Jews with Muslims and native Belgians revealed, first, that Jews were no different from the other two groups on citizen-of-the-world identity, Scheffé $=-0.08,-0.69$. Similar to Muslims (Saroglou \&

TABLE 2

Means and Standard Deviations of Measures

\begin{tabular}{lcc}
\hline & $M$ & $S D$ \\
\hline Values & & \\
Tradition & 3.77 & 0.82 \\
Conformity & 4.54 & 0.92 \\
Security & 4.70 & 0.62 \\
Self-direction & 4.79 & 0.68 \\
Power & 3.47 & 1.09 \\
Achievement & 4.71 & 0.80 \\
Benevolence & 4.90 & 0.61 \\
Universalism & 4.39 & 0.77 \\
Hedonism & 4.97 & 0.88 \\
Stimulation & 4.13 & 0.92 \\
Religion & & \\
Classic religiousness & 4.25 & 1.55 \\
Emotional religion-spirituality & 4.80 & 1.03 \\
Collective identities & & \\
World citizen & 4.20 & 2.02 \\
European & 3.94 & 1.84 \\
Belgian & 3.83 & 2.08 \\
Jew & 6.72 & 0.68 \\
Jewish religious & 4.17 & 1.26 \\
Jewish cultural & 6.01 & 0.79 \\
Out-group aversion & 8.54 & 2.04 \\
\hline
\end{tabular}




\section{Collective identities}

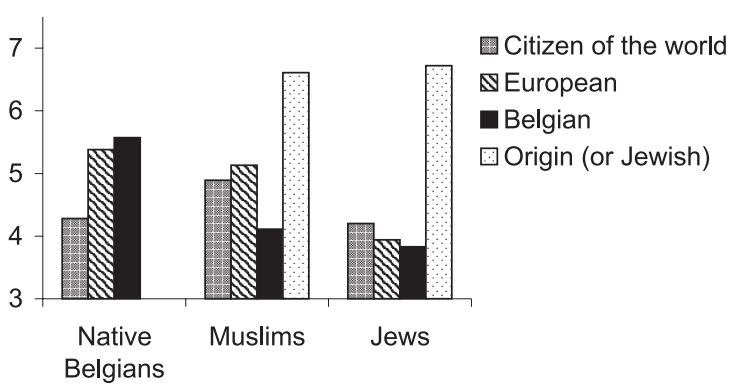

FIGURE 1 Means of collective identities by cultural group. Data for native Belgians and Muslims from Mediterranean countries are adapted from Saroglou and Galand (2004).

\section{Values hierarchy}

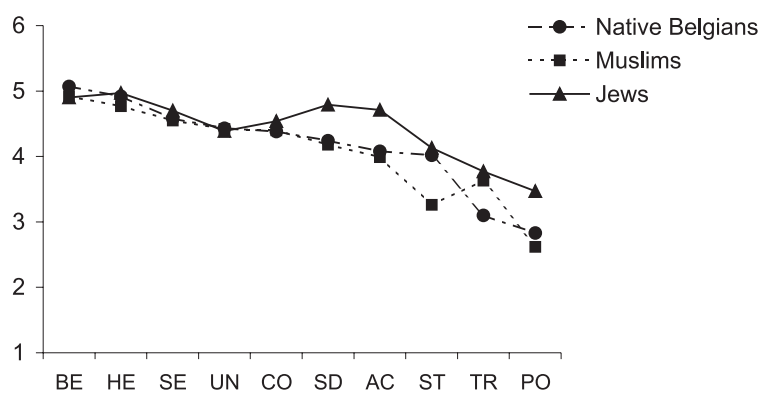

FIGURE 2 Means of values by group. $\mathrm{BE}=$ benevolence; $\mathrm{HE}=$ hedonism; $\mathrm{SE}=$ security; $\mathrm{UN}$ $=$ universalism; $\mathrm{CO}=$ conformity $\mathrm{SD}=$ self-direction; $\mathrm{AC}=$ achievement $\mathrm{ST}=$ stimulation; $\mathrm{TR}$ $=$ tradition $; \mathrm{PO}=$ power . Data for native Belgians and Muslims from Mediterranean countries are adapted from Saroglou and Galand (2004).

Galand, 2004), Jews identified themselves less as Belgians in comparison to native Belgians, Scheffé $=-1.74, p<.001$, and no difference in Belgian identity was observed between Jews and Muslims, -0.28 , $n s$. Interestingly, Jews identified themselves as Europeans less than both native Belgians, $-1.44, p<.001$, and Muslims, $-1.18, p<.001$.

As depicted in Figure 2, value hierarchy was moderately similar between Jews and Muslims, Kendall's $\tau=.60, p<.05$, or native Belgians, .64, $p<.01$, but less so than that between native Belgians and Muslims (Kendall's $\tau=.91, p<.001$; 
Saroglou \& Galand, 2004). Interesting differences came out when comparing Jews with Muslims and native Belgians on the mean importance attributed to each value. Jews valued achievement, power, and self-direction more than Muslims did, Scheffé $=0.71,0.86, p<.001,0.61, p<.01$, and native Belgians, Scheffé $=0.64$, $0.65, p<.001,0.55, p<.01$. In addition, they valued tradition more than native Belgians did, 0.90, $p<.001$ (as did Muslims; Saroglou \& Galand, 2004), and they valued stimulation more than Muslims did, $0.86, p<.01$ (as did native Belgians; Saroglou \& Galand, 2004). Finally, Jews were higher in classic religiousness, $M=$ $4.25, S D=1.55$, than native Belgians were, $M=2.98, S D=1.76$, Scheffé $=1.27, p$ $<.001$, but were less religious than Muslims, $M=6.23, S D=1.15$, Scheffé $=-1.07$, $p<.01$.

\section{Values and Collective Identities}

We conducted correlations of values with the two Jewish identities, the three other collective identities (Belgian, European, and citizen of the world), and the aversive out-group attitude (Table 3). As recommended by Schwartz (1992), partial correlations were conducted, controlling for mean importance attributed to all values. In many cases, a contrast became apparent between ethnic identities (Jewish) and open collective ones. Jewish religious identity was positively related to tradition and power; Jewish cultural identity was positively related to security and hedonism and negatively related to self-direction and universalism; and out-group aversion was positively related to security, power, and hedonism but negatively related to self-transcendence values (benevolence and universalism). Conversely, cosmopolitan identity was positively related to universalism and negatively to security, power, and hedonism; both European and Belgian identities were positively associated with self-direction; in addition, the former was negatively associated with tradition and power whereas the latter was negatively associated with security. Finally, both cosmopolitan and European identities were related to high conformity.

\section{Religion and Collective Identities}

As detailed in Table 3, both religious dimensions were strongly (classic religiousness) or moderately (emotional religion-spirituality) related to Jewish religious identity; they were moderately related to Jewish cultural identity. Also note that Jewish cultural identity was more important than Jewish religious identity, $F(1$, $70)=171.04, p<.001$ (see means in Table 2). Belgian identity was unrelated to Jewish identity (religious and cultural) and to religion measures. However, Jewish religious identity (but not cultural identity) and classic religiousness (but not emotional religion-spirituality) were negatively related to the identification of oneself as European. Similarly, Jewish religious identity (but not cultural identity) was negatively related to self-identification as a citizen of the world, whereas emo- 
TABLE 3

Correlates (Values, Religion) of Jewish Identity, Other Collective Identities, and Out-group Aversion

\begin{tabular}{lcccccc}
\hline & $\begin{array}{c}\text { Jewish } \\
\text { Religious } \\
\text { Identity }\end{array}$ & $\begin{array}{c}\text { Jewish } \\
\text { Cultural } \\
\text { Identity }\end{array}$ & $\begin{array}{c}\text { Out-group } \\
\text { Aversion }\end{array}$ & $\begin{array}{c}\text { Citizen } \\
\text { of the } \\
\text { World }\end{array}$ & European & Belgian \\
\hline Values & & & & & & \\
$\quad$ Tradition & $.54^{* * *}$ & -.11 & .00 & -.04 & $-.30^{* *}$ & -.03 \\
Conformity & .06 & .04 & -.14 & $.22^{*}$ & $.26^{*}$ & .04 \\
Security & -.05 & $.30^{* *}$ & $.25^{*}$ & $-.18+$ & .08 & $-.17+$ \\
Self-direction & -.14 & $-.17+$ & -.08 & .00 & $.26^{*}$ & $.23^{*}$ \\
Power & $.27^{*}$ & .07 & $.45^{* * *}$ & $-.32^{* *}$ & $-.25^{*}$ & .03 \\
Achievement & -.11 & .01 & .13 & -.07 & .10 & .11 \\
Benevolence & -.10 & .06 & $-.19+$ & .10 & -.01 & $-.16+$ \\
Universalism & -.14 & $-.26^{*}$ & $-.38^{* * *}$ & $.26^{* *}$ & -.05 & -.09 \\
Hedonism & -.15 & $.17+$ & $.35^{* *}$ & $-.17+$ & -.01 & .04 \\
$\quad$ Stimulation & -.12 & .13 & -.05 & -.04 & -.05 & -.04 \\
Religion & & & & & & \\
Classic & $.76^{* * *}$ & $.46^{* * *}$ & .14 & -.03 & $-.28^{* *}$ & -.15 \\
Emotional religion-spiritual & $.51^{* * *}$ & $.35^{* *}$ & -.01 & $.23^{*}$ & -.12 & -.09 \\
Collective identities & & & & & & \\
$\quad$ World citizen & $-.19^{*}$ & -.06 & $-.21^{*}$ & - & $.44^{* * *}$ & .11 \\
European & $-.21^{*}$ & -.02 & $-.16+$ & - & - & $.26^{*}$ \\
Belgian & -.08 & -.09 & -.02 & - & - & - \\
Jewish religious & - & $.40^{* * *}$ & $.17+$ & - & - & - \\
Jewish cultural & - & - & .08 & - & - & - \\
\hline
\end{tabular}

Note. $\quad N=71$.

${ }^{\mathrm{a} C}$ Controlling for mean importance on values.

$* p<.05 . * * p<.01 . * * * p<.001 .+p<.10$, one-tailed.

tional religion-spirituality (but not classic religiousness) was positively related to this cosmopolitan identity. Finally, religion measures were unrelated to out-group aversion, but a marginal negative association was found between the latter and Jewish religious identity.

Finally, as with Jewish religious identity, significant associations between religiousness and values (mean importance of values being partialled out) were limited to tradition, $r_{\mathrm{s}}=.41, p<.001$ (classic religiousness), $.32, p<.01$ (emotional religion-spirituality); self-direction, $r_{\mathrm{s}}=-.24, p<.05$ (both religion measures); and power, $.20, p<.05$ (classic religiousness but not emotional religion-spirituality, -.06 , which was also negatively related to security, $-.18, p<.10$ ). The religion-tradition association was not a mere artifact of the item "devout" included in Schwartz's measure of tradition (see also Saroglou \& Galand, 2004), given that the associations decreased but remained significant when this item was excluded from 
the total scores for tradition, $r_{\mathrm{s}}=.20, p<.05$ (classic religiousness), $.18, p<.10$ (emotional religion-spirituality).

\section{DISCUSSION}

In this study, Jewish late adolescents living in Belgium indicated, in the first place, that their Jewish identity is strong, clearly stronger than cosmopolitan, European, and Belgian identities, in a way that is similar to country-of-origin identity among their Muslim immigrant peers living in Belgium; among native Belgians, national identity was also the strongest when compared to transnational identities (Saroglou \& Galand, 2004). This finding suggests that, although multiple identities may exist (note that the means of the second collective identities across all groups were in no case really lower than the median, $M d n=4$ ), people, especially those belonging to ethnic minorities, give a high priority to their origin identity. With regard to Jewish identity, this finding may be considered as being in line with one of the main conclusions of the Cohen and Eisen study (2000) of American Jews: Even when the character of Jewish identity and the ways in which it is expressed may change (for instance, in the context of a postmodern society) and even when the ethnic minority is fully integrated into a larger society, Jewish identity (as with other ethnic identities) remains a primordial and essential way of defining oneself.

In addition, the Belgian identity of Jewish participants was at the same, low level as that in Muslim immigrants. Taken together, these findings did not confirm the hypothesis that Jewish adolescents belonging to a community that is socioeconomically well integrated into Belgian society would feel more "Belgian" than their Muslim peers. It cannot, however, be ruled out that this finding may be due to the fact that the Jewish participants were students in an exclusively Jewish private college, whereas the Muslim participants studied in public schools with their native, Belgian peers. Moreover, it cannot be excluded that the age of the Jewish and Muslim participants of these studies may be responsible for an accentuation of the discrepancy between origin identity and "new" identity (especially country of adoption): The need for distinctiveness may be strong in late adolescence and young adulthood among ethnic and religious minorities or people born into immigrant communities.

Moreover, Jewish identity was neither negatively nor positively related to Belgian identity; once again, this is similar to the case with regard to Belgian identity and country-of-origin identity among Muslim immigrants (Saroglou \& Galand, 2004). As previous research indicates, immigrants' integration into the cultures of their adoptive countries does not necessarily lead to the abandonment of the cultures of origin: Both a mixed-culture model and a predominance of one cultural 
model or another constitute possible courses (Berry, Poortinga, Segall, \& Dasen, 2002; Manço, 1999).

Interestingly, Jews scored lower in European identity than did not only their native Belgian peers but also their Muslim peers. One explanation may be that during the 2002-2004 period, several Israeli and Jewish public personalities and organizations perceived the attitude of the European Union toward anti-Semitic acts and toward Israel's politics as being disrespectful of Jews. An alternative, not incompatible, explanation may be a possible perception of the European Union by European Jews as a political and social entity marked by Christianity-at least by Christian culture, if not by Christian Churches. Interestingly, with regard to this interpretation, Jewish participants with high scores for religiousness also tended not to identify themselves as Europeans. Finally, the distance between a strong Jewish identity and a somewhat weak European identity may have been accentuated by the fact that the participants were students in Jewish private schools and not in public schools that do not adopt any policy on the ethnic origin of their students.

Going further, it appeared that, even on the basis of a few behavioral items, a distinction exists between a religious and a cultural identity. This is in line with previous theoretical and empirical evidence (Dashefsky et al., 2003). Interestingly, the Jewish religious identity was less pronounced than the cultural one. Indeed, our Jewish late adolescents in Belgium seemed to be somewhat marked by secularization: They were less religious than Muslim late adolescents although still more religious than their native Belgian peers. Jewish religious and cultural identities differed on several points: The former was more dependent on the degree of personal religiousness and seemed to reflect low openness to the "external" world, as can be concluded from the weak identifications as citizen of the world and as European. These findings confirm the idea that religion plays an important role in maintaining ethnic identities (Ebaugh, 2003) and that it may even be an obstacle to a widening into more universalist communities (Saroglou et al., 2004; Schwartz \& Huismans, 1995). Interestingly though, it appeared that emotional religion-spirituality leads to a cosmopolitan identity among Jewish late adolescents. This is in line with emerging evidence that when one moves from classic religiosity to spirituality and modern expressions of religiousness, discomfort with universalist values disappears or is replaced by endorsement of these values (Saroglou et al., 2004; Saroglou \& Galand, 2004). Of course, it is still unclear whether this universalism applies to all people or to a broader community within a particular religion (Saroglou \& Galand, 2004).

With regard to values, Jewish participants in this study indicated a hierarchy of values that is similar to those of native Belgians and Muslims (although the degree of similarity seemed to be lower than that between the latter two groups). This can be explained in terms of the universality of such a hierarchy across cultures (Schwartz \& Bardi, 2001) or in terms of similar education and acculturation to social norms and values within the context of Belgian society. However, regarding 
mean importance of values, interesting differences were observed between Jews and native Belgians or Muslims. For Jewish late adolescents, self-enhancement values (power and achievement) and autonomy (self-direction) were highly important in comparison to the other two groups. These findings are intriguing but not easy to interpret. At first glance, they seem to confirm the general stereotypes of Jewish dynamism-emphasis on success, intelligence, and dominance (Wilson, 1996; Wuthnow, 1982). However, to give some credit to this interpretation, one has to consider other Jewish data from other ages, contexts, and countries. For instance, it cannot be ruled out that the socioeconomic status of our participants may be responsible for these findings: Studying in private Jewish schools unique in Brussels, the Jewish adolescents of our study are likely to come from families belonging to an "elite" of the Jewish community. Native Belgians and Muslim immigrants, on the other hand, studied together at the same, de facto "multicultural" public schools, whereas the "elite" schools for native Belgians in Brussels are known to be culturally exclusive. Another interpretation could be that transmission of self-enhancement values is important in families who experienced firstor secondhand consequences of persecution. A third, speculative interpretation could be based on religion: A related finding was suggestive. Religiosity was positively related to power, contrary to what is often the case in other religious groups (Saroglou et al., 2004), although the other significant associations between values and religion (negative for self-direction and positive for tradition) were in line with what is expected on the basis of much previous literature (Saroglou et al., 2004). ${ }^{1}$

Other differences in the importance of values can be understood if we focus on specific characteristics of the other groups. Jewish participants were similar to Muslims in valuing tradition, but native Belgians, who (as mentioned earlier) were the least religious, scored low on this value. Our participants also valued stimulation similarly to native Belgians, that is, less than Muslims. Given that stimulation is defined by excitement, novelty, and challenge in life, this finding may be due to the precarious socioeconomic situation of Muslim immigrants within Belgian society.

\footnotetext{
${ }^{1}$ One interpretation of the religiousness-power positive association could be that the type of religiousness found among the participants in our studies reflects extrinsic rather than intrinsic motivations for being religious. Extrinsic religiousness, unlike intrinsic, has been found to correlate positively with valuing power (Burris and Tarpley, 1998). Interestingly, being religious for in-group-focused identity reasons and not necessarily for spiritual reasons reflects an extrinsic form of religiousness (Bègue \& Morin, 1998) —note, for instance, the absence of association between religiousness and benevolence in this study, which is similar to a study of Greek Orthodox young people (Schwartz \& Huismans, 1995) but contrary to many other studies (Saroglou et al., 2004). In other words, religion may be used for personal and collective empowerment. Cohen and Eisen (2000) noted, for instance, that "Jews do not seem to choose Judaism, or choose among competing forms of Judaism, primarily in terms of beliefs" (p. 197), and Fishman (2004) argued that "rather than being defined as the faith of an individual soul, Jewishness more closely matches [the] commonly recognized definition of an ethnic group" (p. 163).
} 
Finally, values seemed to play some role with regard to narrow (religious and ethnic) identity versus openness to the "external" world — that is, "new" national (Belgian) identity, transnational identities (European and cosmopolitan), and low out-group aversion. We found (although not systematically in every case) that, in line with the results of previous literature (Duriez et al., 2002; Sagiv \& Schwartz, 1995; Saroglou \& Galand, 2004), Jewish adolescents who valued tradition, power, and security and who disliked universalism and self-direction tended to report having strong religious or cultural Jewish identity or being rather closed to contact with out-groups. In contrast, participants who disliked tradition, security, and power and who valued universalism and self-direction tended to report strong cosmopolitan, European, or Belgian identity. An additional positive link with conformity could be understood in terms of the positive quality in societal relationships reflected by this value, defined by Schwartz (1992) as "restraint of actions, inclinations, and impulses likely to upset or harm others and violate social expectations or norms" (p. 9). Finally, unlike Muslim adolescents, whose high hedonism predicted strong European and Belgian identities (Saroglou \& Galand, 2004), hedonism in Jewish participants was related positively to Jewish cultural identity and out-group aversion and negatively to citizen-of-the-world identity. It may be that hedonism has different implications for distanciation from the identity of origin and for openness to the world depending on the socioeconomic status or the degree of integration of an ethnic minority into mainstream society.

The main limitation of the study was the a priori weak generalizability of the findings. As mentioned earlier, participants came from a specific group with regard to age, educational environment, socioeconomic status, living area, and country. Prudence is thus needed to avoid generalizing young Jews of the Diaspora in particular or ethnic minorities in general. For instance, future research should compare young people from an ethnic minority who all go to public schools with young peers from the same population who all go to religious or ethnic schools. Nevertheless, as Cohen and Eisen (2000) argued in the discussion of their U.S. study, there is still room for considering that some results (a) may not be too specific to a particular Jewish group in a specific decade but may emerge from long-term dynamics concerning Jewish identity in a multicultural society and (b) may reflect the realities that every ethnic minority group experiences within the broad surrounding society. If we come to our results, we may, for instance, suspect that the similarities that we found between young Jews, Muslims, and natives in the hierarchy of collective identities (high emphasis on the country-of-origin identity versus country-of-adoption identity) as well as the role of religion and conservation versus self-transcendence values in relation to this priority, may be typical of European (and possibly American) Jews and other ethnic minority groups in general. On the other hand, it is unclear - and is thus particularly worthy of future investigation - whether the weak European identity that we found is characteristic of only the participants in our study or of Jews in Europe in general. Similarly, it 
would be worthwhile to investigate whether the strong emphasis on autonomy and power and the interference of religion with the latter value reflect a specifically Jewish reality or are confined to our sample: Previous studies have suggested that these two features do not seem to characterize other religions and cannot be due to immigrant/ethnic-minority status versus native status (e.g., Saroglou et al., 2004; Saroglou \& Galand, 2004).

Multiple identities in multicultural societies are becoming an increasingly important issue in a globalized world. Jewish identity within this context constitutes a complex, fascinating case for study. It is only with the accumulation of studies of specific samples within specific contexts that researchers will be able to distinguish between universal and context-specific characteristics in such sensitive areas of research where fundamental psychosocial dynamics meet a variety of cultures and historical contexts.

\section{ACKNOWLEDGMENTS}

We wish to thank Steven Stern and Robert Hogenraad for their helpful comments and suggestions on an earlier version of the manuscript.

\section{REFERENCES}

Bègue, L., \& Morin, M. (1998). Pratiques sociales, religion et jugement moral [Social practices, religion, and moral judgment]. Les Cahiers Internationaux de Psychologie Sociale, 37, $23-44$.

Berry, J. W., Poortinga, Y. H., Segall, M. H., \& Dasen, P. R. (2002). Cross-cultural psychology: Research and applications (2nd ed.). Cambridge: Cambridge University Press.

Brachfeld, S. (2001). Ils ont survécu: Le sauvetage des Juifs en Belgique occupée [They survived: The rescue of Jews in occupied Belgium]. Brussels, Belgium: Racine.

Bréchon, P. (2003). Integration into Catholicism and Protestantism in Europe: The impact on moral and political values. In L. Halman \& O. Riis (Eds.), Religion and secularizing society: The Europeans' religion at the end of the 20th century (pp. 114-161). Leiden, Netherlands: Brill.

Burris, C. T., Branscombe, N. R., \& Jackson, L. M. (2000). "For God and country": Religion and the endorsement of national self-stereotypes. Journal of Cross-Cultural Psychology, 31, 517-527.

Burris, C. T., \& Tarpley, W. R. (1998). Religion as being: Preliminary validation of the Immanence scale. Journal of Research in Personality, 32, 55-79.

Campiche, R. J. (Ed.). (1997). Cultures jeunes et religions en Europe [Youth culture and religions in Europe]. Paris: Cerf.

Cohen, S. M., \& Eisen, A. M. (2000). The Jew within: Self, family, and community in America. Bloomington, IN: Indiana University Press.

Dashefsky, A., Lazerwitz, B., \& Tabory, E. (2003). A journey of the "straight way" or the "roundabout path": Jewish identity in the United States and Israel. In M. Dillon (Ed.), Handbook of the sociology of religion (pp. 240-260). Cambridge: Cambridge University Press. 
Duriez, B., Luyten, P., Snauwaert, B., \& Hutsebaut, D. (2002). The importance of religiosity and values in predicting political attitudes: Evidence for the continuing importance of religiosity in Flanders (Belgium). Mental Health, Religion, and Culture, 5, 35-54.

Ebaugh, H. R. (2003). Religion and the new immigrants. In M. Dillon (Ed.), Handbook of the sociology of religion (pp. 225-239). Cambridge: Cambridge University Press.

Elazar, D. J. (1999). Jewish religious, ethnic, and national identities: Convergence and conflicts. In S. M. Cohen (Ed.), National variations in Jewish identity (pp. 35-52). Albany, NY: State University of New York Press.

Fishman, S. B. (2004). Double or nothing? Jewish families and mixed marriage. Lebanon, NH: Brandeis University Press.

Halman, L. (2001). The European values study, a third wave: Source book of the 1999/2000 European values study surveys. Tilburg, Netherlands: Tilburg University.

Khader, B., \& Roosens, C. (Eds.). (2004). Belges et Arabes: Voisins distants, partenaires nécessaires [Belgians and Arabs: Distant neighbors, necessary partners]. Louvain-la-Neuve, Belgium: Presses Universitaires de Louvain.

Liebman, C. (2001). A research agenda for American Jews. Ramat Gan, Israel: Argov Center for the Study of Israel and the Jewish People.

Manço, A. (1999). Intégration et identités: Stratégies et positions des jeunes issus de l'immigration [Integration and identities: Strategies and positions of young people born of immigration]. Brussels, Belgium: DeBoeck.

Roccas, S., Sagiv, L., Schwartz, S. H., \& Knafo, A. (2002). The Big Five personality factors and personal values. Personality and Social Psychology Bulletin, 28, 789-801.

Sagiv, L., \& Schwartz, S. H. (1995). Value priorities and readiness for out-group social contact. Journal of Personality and Social Psychology, 69, 437-448.

Saroglou, V. (2002). Beyond dogmatism: The need for closure as related to religion. Mental Health, Religion, and Culture, 5, 183-194.

Saroglou, V., Delpierre, V., \& Dernelle, R. (2004). Values and religiosity: A meta-analysis of studies using Schwartz's model. Personality and Individual Differences, 37, 721-734.

Saroglou, V., \& Galand, P. (2004). Identities, values, and religion: A study among Muslim, other immigrant, and native Belgian young adults after the 9/11 attacks. Identity: An International Journal of Theory and Research, 4, 97-132.

Schreiber, J.-P. (1996). L'immigration juive en Belgique du Moyen Age à la Première Guerre mondiale [Jewish immigration in Belgium from the Middle Age to the First World War]. Brussels, Belgium: Editions de l'Université Libre de Bruxelles.

Schreiber, J.-P. (2002). Dictionnaire biographique des Juifs de Belgique: Figures du judaïsme belge (XIXe-XXe siècles) [Biographical dictionary of Jews from Belgium: Faces of Belgian Judaism (19-20th centuries)]. Brussels, Belgium: De Boeck Université.

Schwartz, S. H. (1992). Universals in the content and structure of values: Theoretical advances and empirical tests in 20 countries. In M. Zanna (Ed.), Advances in experimental social psychology (Vol. 25, pp. 1-65). Orlando, FL: Academic Press.

Schwartz, S. H., \& Bardi, A. (2001). Value hierarchies across cultures: Taking a similarities perspective. Journal of Cross-Cultural Psychology, 32, 268-290.

Schwartz, S. H., \& Huismans, S. (1995). Value priorities and religiosity in four western religions. Social Psychology Quarterly, 58, 88-107.

Schwartz, S. H., \& Sagiv, L. (1995). Identifying culture-specific in the content and structure of values. Journal of Cross-Cultural Psychology, 26, 92-116.

Steinberg, M. (1998). Un pays occupé et ses juifs: Belgique entre France et Pays-Bas [An occupied country and its Jews: Belgium between France and the Netherlands]. Gerpinnes, Belgium: Quorum.

Voyé, L., \& Dobbelaere, K. (2001). De la religion: Ambivalences et distancements [On religion: Ambivalences and distances]. In B. Bawin-Legros, L. Voyé, K. Dobbelaere, \& M. Elchardus (Eds.), 
Belge toujours: Fidélité, stabilité tolérance. Les valeurs des Belges en l'an 2000 [Always Belgian: Fidelity, stability, tolerance. The values of Belgians in 2000] (pp. 143-175). Brussels, Belgium: De Boeck Université.

Wilson, T. C. (1996). Compliments will get you nowhere: Benign stereotypes, prejudice, and anti-semitism. Sociological Quarterly, 37, 465-479.

Wuthnow, R. (1982). Anti-semitism and stereotyping. In A. G. Miller (Ed.), In the eye of the beholder: Contemporary issues in stereotyping (pp. 137-187). New York: Praeger. 